Research article

\title{
Irrigation systems in smart cities coping with water scarcity: The case of Valdebebas, Madrid (Spain)
}

\author{
Freddy Canales-Ide*, Sergio Zubelzu, Leonor Rodríguez-Sinobas \\ HIDER Research Group, Hydraulics for Irrigation, Escuela Técnica Superior de Ingeniería Agronómica, Alimentaria y de Biosistemas (ETSIAAB), Universidad Politécnica de \\ Madrid, Avenida Puerta del Hierro 2, 28040, Madrid, Spain
}

\section{A R T I C L E I N F O}

\section{Keywords:}

Water management

Urban irrigation

Landscaping

Smart cities

Water scarcity

Subsurface drip irrigation

\begin{abstract}
A B S T R A C T
This study is aimed at assessing the performance of irrigation systems in Valdebebas, an urban development located in Madrid (Spain), as an example of smart irrigation. Subsurface drip irrigation (SDI) is the major irrigation method, although surface drip irrigation (DI) is also applied in a small area. The irrigation scheduling is made by the park manager, using the plant water requirements based on the reference evapotranspiration retrieved from a nearby weather station, and a plant coefficient $\mathrm{K}_{\mathrm{C}}$. In this study, plant water requirements were estimated using the Water Use Classification of Landscape Species (WUCOLS) III method, in which plant water requirements are based on the composite of plant species and not on a single species, as in the case for classical crop coefficients. Water use efficiency is assessed by the relative water supply and the relative rainfall supply indicators. The results showed that the irrigation was better managed using the estimations of the park manager compared to the WUCOLS method although the irrigation scheduling is based only on the climatic information and does not consider other variables such as the soil water content.
\end{abstract}

\section{Introduction}

In arid and semiarid climates, conventional water resources (surface and subsurface water) have been traditionally used to irrigate parks, gardens, and sports facilities. They accounts for $60 \%$ of the total water consumption in urban areas (Brandt et al., 2017; Mini et al., 2014; Reyes-Paecke et al., 2019; Salvador et al., 2011).

Since urban water needs are high and conventional water resources are scarce, cities with a long dry season, such as Madrid, are seeking to maximize the sustainability of urban living by developing irrigation infrastructure that reuses treated wastewater from wastewater treatment facilities (Angelakis and Gikas, 2014; Ayuntamiento, 2018). However, the use of reclaimed wastewater does not ensure the optimum efficiency of the irrigation process. The criteria for operation in irrigation systems affect overall sustainability. Their lack of efficiency and the inappropriate irrigation scheduling can result either in over- or under-irrigation. For example, Salvador et al. (2011) observed that irrigation in Zaragoza's gardens (Spain) exceeded the water requirements by up to $225 \%$. Martínez Gimeno (2014) reported that about $43 \%$ of water could be saved using an automated irrigation system at the Technical University of Valencia (Spain) by adjusting the irrigation time to the water needs of the most drought-sensitive species. Pérez-
Urrestarazu et al. (2018) reported that some gardens in the Real Alcazar historic parks in Seville (Spain) were overwatered by up to $700 \%$, and others received only $32 \%$ of their total water requirements; these results could be caused by non-standardized irrigation and the use of different irrigation methods across the gardens. The same trends have been also reported in other Mediterranean climate areas, such as Chile (Reyes-Paecke et al., 2019), California (Mini et al., 2014), and Australia (Nouri et al., 2013).

The term 'smart irrigation' has been defined, as part of the global concept of smart cities, in the context of water scarcity and the need for water use efficiency. Smart irrigation includes a group of techniques and criteria aimed at optimal irrigation management, which requires an accurate determination of plant water requirements and optimal efficiency of irrigation systems in order to minimize water losses and to provide optimum use of the water supplies.

The accurate estimation of plant water requirements is a key factor. Plant water requirements can be measured using indirect methods, such as the use of reference evapotranspiration $\left(\mathrm{ET}_{0}\right)$ particularized to ornamental species (Costello, 1994), or direct methods, using either soil moisture sensors (SMS) (Patil and Desai, 2013), or satellite-based systems (Hof and Wolf, 2014; Mateos et al., 2013). Applying the selected methods can reduce water demand. For example, Haley et al. (2007)

\footnotetext{
* Corresponding author.

E-mail addresses: freddy.canales.ide@alumnos.upm.es (F. Canales-Ide), sergio.zubelzu@upm.es (S. Zubelzu), leonor.rodriguez.sinobas@upm.es (L. Rodríguez-Sinobas).
} 
observed that water consumption was reduced by $30 \%$, compared with traditional management, when the irrigation system was adjusted to the $\mathrm{ET}_{0}$ of the previous year, and was reduced by $50 \%$ using SMS.

Optimum automation of irrigation systems and real-time monitoring are tools to achieve optimum efficiency, to minimize water losses, and to ensure maximum reuse. Recently, a number of studies have been carried out on the suitability and the benefits of monitoring and automation of irrigation systems (Todorovic et al., 2016). Some of these studies focus on techniques based on the Internet of Things for monitoring and controlling irrigation systems (Zhang, 2011). Smart controllers can achieve water use efficiency if they are coupled with smart design irrigation systems (Davis and Dukes, 2015).

In addition to the requirements for optimum management of the irrigation infrastructure, proper hydraulic design and operation of the irrigation systems is important for ensuring the sustainability of the entire process. Many studies have identified trickle irrigation as the most efficient irrigation system, if it is properly designed and operated (Vidana Gamage et al., 2018). The drops of water are discharged by emitters near the plant, either on or beneath the soil surface. Among the advantages of trickle irrigation systems are reduced water stress, ease of automation and fertilization, reduced costs of design and operation (Subbaiah, 2013), improved irrigation efficiency (Yao et al., 2011), and a significant reduction in the wetted soil surface (Moncef and Khemaies, 2016).

The design of the Valdebebas urban development in Madrid (Spain) was guided by the smart cities development criteria (Rodríguez-Sinobas et al., 2018). The urban parks are mostly irrigated with subsurface drip irrigation (SDI) and limited areas are irrigated using surface drip irrigation (DI). The operation of these systems is centrally automated through a personal computer with software connected to a local weather station from which real-time data is collected. In general, there is a lack of studies addressing the optimum operation criteria for smart irrigation systems. For example, in Valdebebas, despite the modern design of the installed infrastructure, the actual hydraulic performance of the irrigation system is not controlled so there are doubts about the actual efficiency of the smart infrastructure.

Therefore, this study is aimed at assessing the performance of the smart irrigation system.

\section{Case study: Valdebebas urbanization}

The urban parks and gardens of Valdebebas are located in northeast Madrid (Fig. 1). The climate of the Madrid metropolitan area is considered transitional between the Cold Semiarid and Mediterranean climates. According to the Köppen classification, the city has the Csa climatic type; rainfall is concentrated in autumn and spring (Fig. 2), with an average aggregated annual rainfall of $435.8 \mathrm{~mm}$, and a mean temperature of $14.59^{\circ} \mathrm{C}$, calculated from 1970 to 2000 .

The urban parks have an upper layer of sandy loam soil which holds the plant's roots. Several soil samples at different depths were collected for analysis of their physical properties, which are presented in Table 1, as follows: $\theta_{\text {cc }}$ is the soil water content at field capacity (which equals a matric suction head of $1 / 3 \mathrm{~atm}), \theta_{\mathrm{PWP}}$ is the soil water content at permanent wilting point (corresponding to a suction matric head of $15 \mathrm{~atm}$ ), $\mathrm{CF}$ is the coarse fragments, and $\mathrm{K}_{\mathrm{S}}$ is the hydraulic saturated conductivity.

The urban development design has incorporated xeriscaping concepts, such as the selection of plant species with low water requirements and tolerance to water stress conditions; the areas covered with plants were optimized, and the lawn areas were minimized. Fig. 3 shows some pictures of the urban parks.

The urban development includes 1065 ha of parks that are irrigated using reclaimed wastewater fed from two $5000 \mathrm{~m}^{3}$ tanks and two pumping stations. The irrigation system covers 20 ha of vegetation, divided into 34 single irrigation zones (Fig. 1). Control and measurement elements (Woltzman flow meter, a pressure reducer, pressure sustainer valve, pressure transductor, and an automated-cleaning disc filter) are placed at the upstream end of each irrigation zone.

For each irrigation zone, several sectors were defined depending on the plants' physiology. Each irrigation system in the sectors is operated with an electric valve commanded by a Site Control software provided by RainBird $<$ SUP $>$ R $<$ /SUP $>$ (USA). The specific characteristics of each irrigation system are presented in Table 2.

The irrigation season usually begins in May and ends in October. Irrigation events are scheduled by the irrigation manager as follows: lawn is irrigated daily, bushes and deciduous shrubs are irrigated every other day, and trees are irrigated once or twice per week. The irrigation depth is determined by the reference evapotranspiration $\mathrm{ET}_{0}$, measured at the weather station located at Valdebebas, and the crop coefficients which are assigned by the irrigation manager considering his expertise in plant development. The assigned values for lawn (LAW) were 0.9, between June and August, and 0.8 for the other months. The values for mixed shrubs and bushes (COL), trees (TREE) and shrubs and flower collections (SHR) were 0.8, between June and August, and 0.7 for the remainder months. The time for each irrigation event is determined by the Site Control Software taking into account the water requirements and the selected irrigation frequency but it does not consider the soil water availability.

\section{Methodology}

In order to test the performance of the irrigation system and the suitability of the management of the irrigation network, the irrigation zones: 107, 108, 202, 203, 204, 301 and 302 (see Fig. 1), representative of the entire district, were selected and their water requirements were estimated with the WUCOLS III methodology (Costello and Jones, 2014).

The climatic data were recorded daily in 2017 from the weather station located at Valdebebas district.

\subsection{Landscape water requirements}

The WUCOLS III methodology estimates a landscape coefficient $\left(\mathrm{K}_{\mathrm{L}}\right)$ using the water requirements of different plant species in a park. It is composed of three coefficients: $\mathrm{K}_{\mathrm{d}}$, the plant density coefficient, $\mathrm{K}_{\mathrm{mc}}$, the microclimate coefficient, and $\mathrm{K}_{\mathrm{s}}$, the plant species coefficient (see eq. (1)). The park water requirements, $\mathrm{ET}_{\mathrm{L}}$, are then determined by multiplying the reference evapotranspiration $\left(\mathrm{ET}_{0}\right.$ ) and $\mathrm{K}_{\mathrm{L}}$ (eq. (2)).

$K_{L}=K_{s} K_{m c} K_{d}$

$\mathrm{ET}_{\mathrm{L}}=\mathrm{ET}_{0} \mathrm{~K}_{\mathrm{L}}$

Plants with similar water requirements were grouped at the park design stage to optimize the irrigation efficiency. Hence, in order to estimate $K_{s}$ for each park, the same value was considered for each group. Table 3 shows the groups, the species, the $K_{s}$ for each specie (retrieved from Costello (1994); Costello and Jones (2014)), and the adopted $K_{s}$ for each group. The $K_{s}$ value $\left(K_{s}\right.$-group, plant type) was calculated as the average of the $K_{s}$ value of each specie within the group ( $\mathrm{K}_{\mathrm{s}}$-śpecie). For the deciduous species, the $\mathrm{K}_{\mathrm{s}}$ value was minored $20 \%$ outside the maximum demand period (April, May, October, and November).

The microclimate coefficient $\left(\mathrm{K}_{\mathrm{mc}}\right)$ is based on the area occupied by surrounding open areas, dark pavements, walls reflecting solar radiation, shadows or open water bodies. $\mathrm{K}_{\mathrm{d}}$ corresponds to the plant density coefficient which determines the leaf area exposed to transpiration. Table 4 presents the selected $K_{s}$ and $K_{d}$ values for each selected zone.

\subsection{Irrigation performance}

The performance of the irrigation management was assessed with two indicators: the relative water supply (RWS) (eq. (3)) and the 


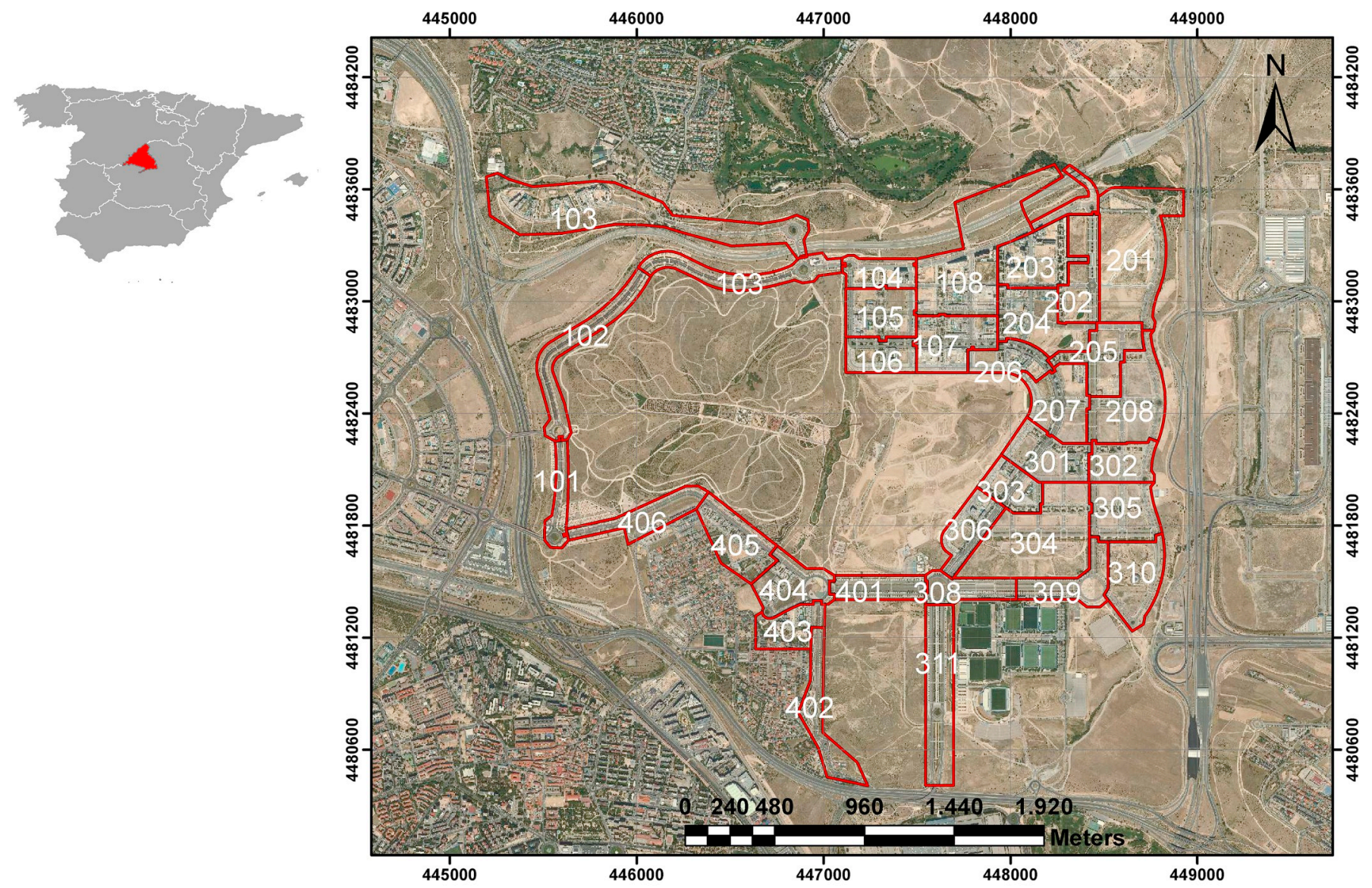

Orthophoto Image. Plan Nacional de Ortofotografía Aérea de España (PNOA). Instituto Geográfico Nacional

Fig. 1. Location of Valdebebas urban development and their irrigation zones.

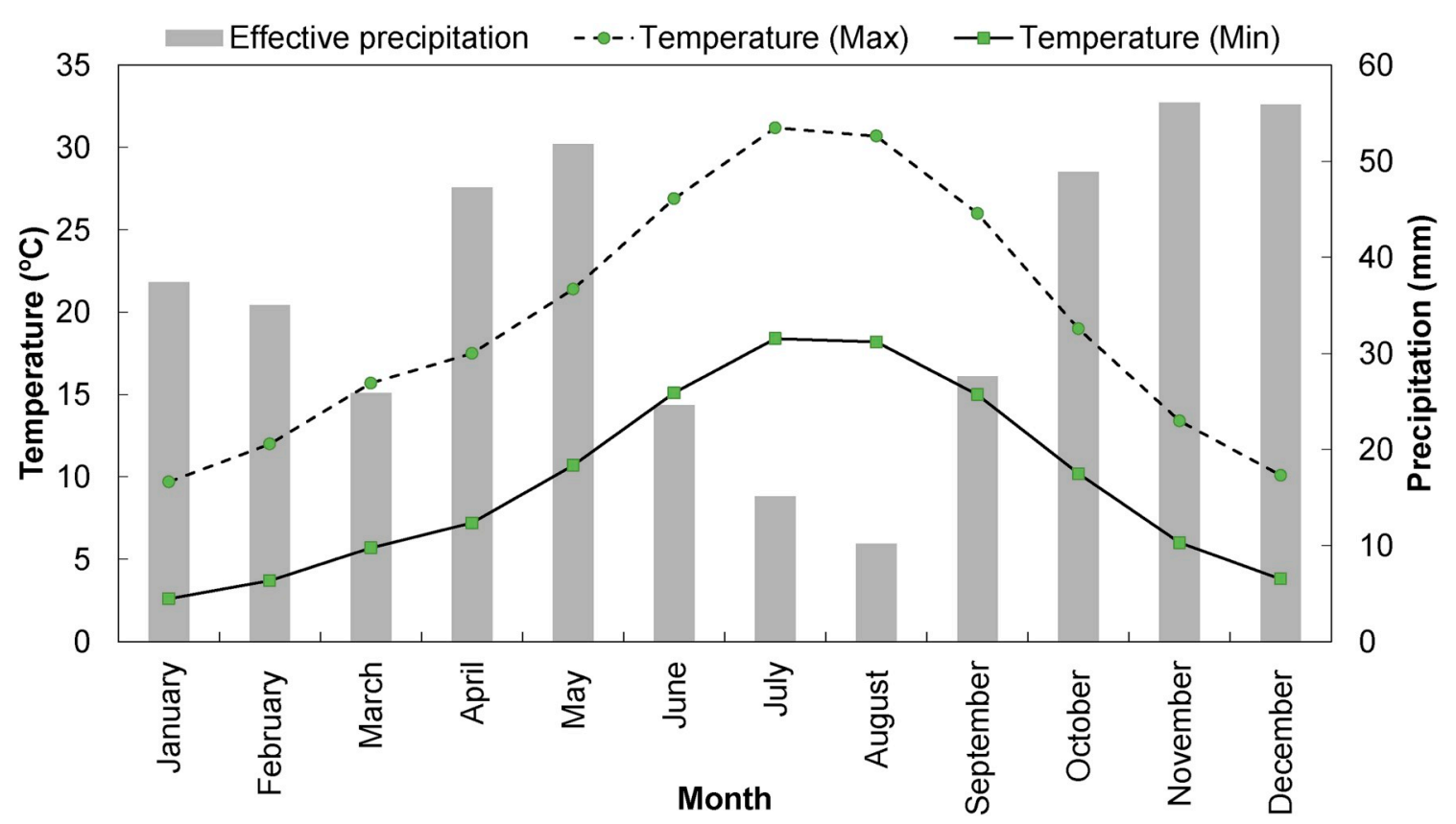

Fig. 2. Average climatic data collected from the weather station Madrid-Retiro 
Table 1

Physical properties from planting soil in the urban parks.

\begin{tabular}{llllll}
\hline Depth & $\theta_{\mathrm{CC}}$ & $\theta_{\mathrm{PWP}}$ & Density & $(1-\mathrm{CF})(\%)$ & $\mathrm{K}_{\mathrm{S}}\left(\mathrm{mm} \mathrm{min}^{-1}\right)$ \\
\cline { 1 - 4 }$(\mathrm{cm})$ & $\left(\mathrm{cm}^{3} \mathrm{~cm}^{-3}\right)$ & $\left(\mathrm{cm}^{3} \mathrm{~cm}^{-3}\right)$ & $\left(\mathrm{g} \mathrm{cm}^{-3}\right)$ & & \\
\hline $0-15$ & 0.13 & 0.09 & 0.98 & 64 & 3.67 \\
$16-35$ & 0.11 & 0.07 & 1.25 & 70 & 2.01 \\
35 & 0.18 & 0.12 & 1.55 & 75 & 0.75 \\
\hline
\end{tabular}

relative rainfall supply (RRS) (eq. (4)).

RWS $=\frac{\mathrm{Hb}+\mathrm{P}_{\mathrm{e}}}{\mathrm{ET}}=\frac{\mathrm{H}_{\mathrm{b}}+0.75\left(\mathrm{P}_{5}\right)}{\mathrm{ET}}$

$R R S=\frac{P_{e}}{E T}$

Where: ET is the water requirement, $\mathrm{H}_{\mathrm{b}}$ the applied irrigation depth and $\mathrm{P}_{\mathrm{e}}$ the effective precipitation, which was estimated as a percentage of the total precipitation greater than $5 \mathrm{~mm}, \mathrm{P}_{5}$.

The index RWS is classified into three groups: stressed (RWS $<0.7$ ), optimum $(0.7<$ RWS $<1.5)$ and overwatered (RWS > 1.5) (Levine, 1982). Thus, values close to 1 indicate optimal irrigation management.

The indicators were calculated from May to October 2017.

\subsection{Water balance}

The water balance, as it is defined in Eq. (5), was used to estimate the variation in soil water content $\Delta \theta$ during the irrigation season which would correspond to soil water availability for plants. The water balance was computed using daily data from the Valdebebas weather station.

$\mathrm{I}+\mathrm{P}_{\mathrm{e}}=\mathrm{ET}+\mathrm{D}+\Delta \theta$

where: $I$ is the irrigation, $P_{e}$ the effective precipitation, ET the
Table 2

Plant types and irrigation systems.

\begin{tabular}{lllll}
\hline Plant typology & $\begin{array}{l}\text { Irrigation } \\
\text { system }\end{array}$ & $\begin{array}{l}\text { Emitter } \\
\text { nominal } \\
\text { flow rate }\end{array}$ & Emitter spacing & $\begin{array}{l}\text { Irrigation } \\
\text { depth }\end{array}$ \\
\cline { 3 - 5 } & & $\left(\mathrm{L} \mathrm{h}^{-1}\right)$ & $(\mathrm{m})$ & $\left(\mathrm{mm} \mathrm{h}^{-1}\right)$ \\
\hline Lawn & SDI & 0.8 & $0.15 \times 0.15$ & 20.7 \\
Bushes & SDI & 0.7 & $0.3 \times 0.3$ & 9.2 \\
Trees-parks & SDI & 2.3 & $0.3 \times 0.3$ & 20.7 \\
Trees- avenue & DI - SDI & 2.3 & $0.5 \times 0.5$ & 9.0 \\
Shrubs -Deciduous & DI & 2.3 & $0.5 \times 0.5$ & 9.0 \\
Mixed shrubs- & DI & 1.0 & $0.3 \times 0.3$ & 9.2 \\
\multicolumn{1}{c}{ Roundabouts } & & & & \\
\hline
\end{tabular}

evapotranspiration, $\mathrm{D}$ the seepage and $\Delta \theta$ the soil water content variation between two intervals.

\section{Results}

The following results refer to the data collected daily from the weather station at Valdebebas from May to October 2017.

\subsection{Comparison between estimated requirements and volumes applied}

The $\mathrm{K}_{\mathrm{C}}$ and $\mathrm{K}_{\mathrm{L}}$ coefficients are depicted for each plant type in Fig. 4 for the evaluated sectors.

The $\mathrm{K}_{\mathrm{L}}$ coefficients are smaller than $\mathrm{K}_{\mathrm{C}}$ except in the LAW category and its $K_{s}$ value assigned by the WUCOLS III procedure is about 0.8 . If the irrigation depth were determined with the coefficients presented in Fig. 4, the WUCOLS III procedure would give smaller irrigation requirements than those calculated using $\mathrm{K}_{\mathrm{C}}$. Therefore, if the water requirements for TREE, COL, SHR were estimated using $\mathrm{K}_{\mathrm{L}}$, they would be reduced by $36 \%, 43 \%$, and $39 \%$, respectively, and water requirements
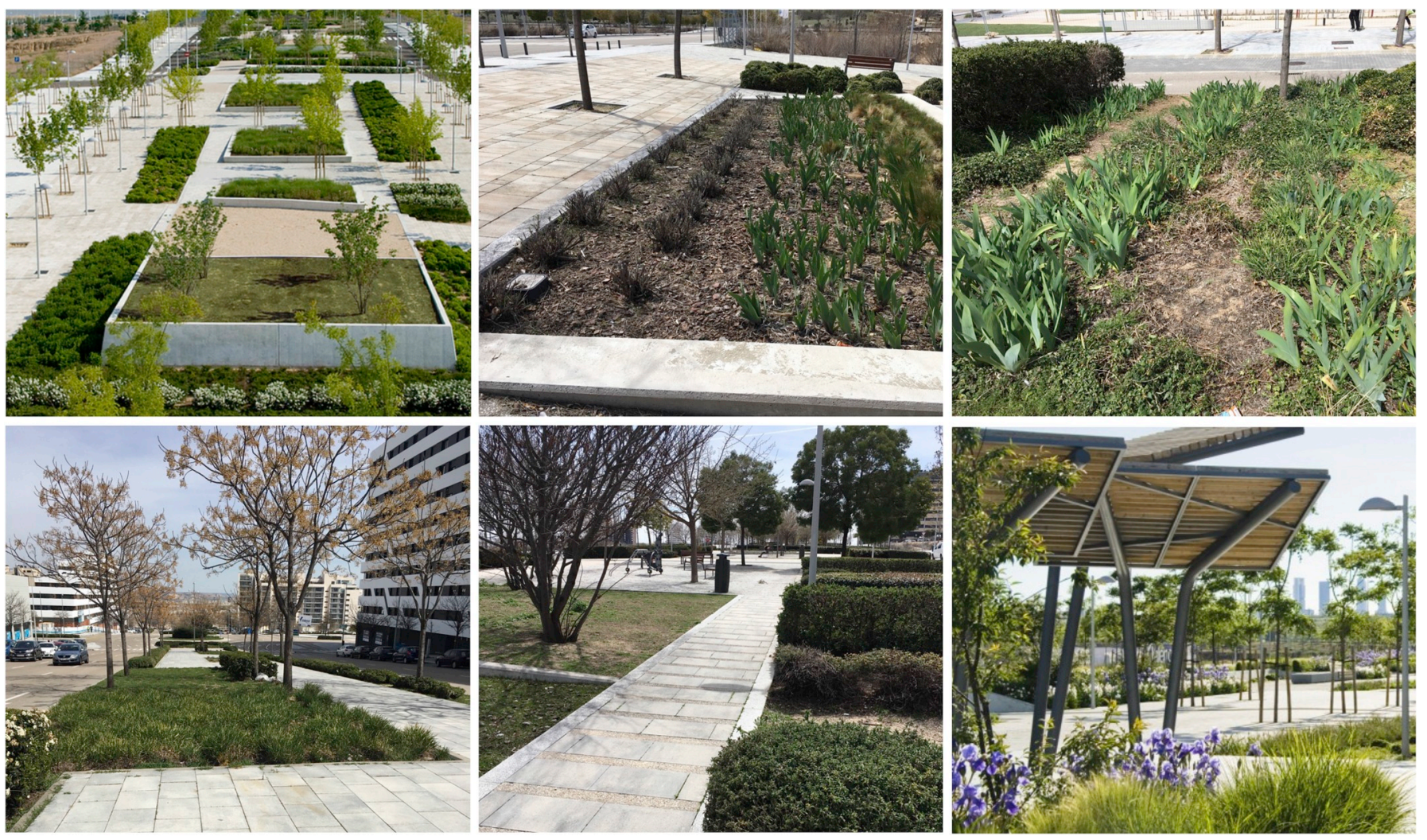

Fig. 3. Examples of landscaping characteristics in Valdebebas. 
Table 3

Adopted $\mathrm{K}_{\mathrm{s}}$ coefficient for each species' group.

\begin{tabular}{|c|c|c|c|c|c|}
\hline Plantation type & Genus & sp. & Variety & $\mathrm{K}_{\mathrm{s}}$ specie & $\mathrm{K}_{\mathrm{s}}$ Group-Plant type \\
\hline \multirow[t]{20}{*}{ COL } & Viburnum & tinus & & 0.5 & 0.5 \\
\hline & Viburnum & tinus & 'Eve Price' & 0.5 & \\
\hline & Viburnum & tinus & 'Purpureum' & 0.5 & \\
\hline & Escallonia & ssp. & 'Iveyi' & 0.5 & 0.45 \\
\hline & Lonicera & nitida & 'Elegant' & 0.4 & \\
\hline & Pittospotum & tobira & 'Nana' & 0.45 & 0.45 \\
\hline & Festuca & glauca & & 0.4 & 0.4 \\
\hline & Tulbaghia & violacea & & 0.4 & \\
\hline & Tulbaghia & violacea & 'White' & 0.4 & \\
\hline & Lavandula & angustifolia & 'Hitcote Pink' & 0.3 & \\
\hline & Gaura & lindheimeri & & 0.5 & \\
\hline & Gaura & lindheimeri & 'Siskiyou Pink' & 0.5 & \\
\hline & Cistus & X skanbergi & & 0.3 & \\
\hline & Cistus & florentinus & & 0.3 & \\
\hline & Liriope & muscari & & 0.5 & 0.4 \\
\hline & Iris & germanica & & 0.3 & \\
\hline & Pennisetum & alopecuroides & & 0.2 & \\
\hline & Tulbaghia & violacea & & 0.4 & \\
\hline & Tulbaghia & violacea & 'White' & 0.4 & \\
\hline & Hedera & hibernica & 'Sagitifolia' & 0.5 & \\
\hline \multirow[t]{5}{*}{ SHR } & Chrysanthemun & leaucanthemum & & 0.5 & \\
\hline & Iris & ssp. & Multiples & 0.6 & \\
\hline & Hemerocallis & $s s p$ & Multiples & 0.5 & \\
\hline & Trachelospermun & jasminoides & 'Tricolor' & 0.5 & \\
\hline & Rosa & ssp. & & 0.5 & \\
\hline LAW & Cynodon & dactylon & & 0.8 & \\
\hline \multirow[t]{8}{*}{ TREE } & Acacia & dealbata & & 0.2 & \\
\hline & Acer & platanoides & & 0.6 & \\
\hline & Cercis & siliquastrum & 'Multistem' & 0.2 & \\
\hline & Lagerstroemia & indica & 'Rosea' & 0.4 & \\
\hline & Morus & alba & 'Fruitless' & 0.4 & \\
\hline & Sophora & japonica & & 0.4 & \\
\hline & Sorbus & aria & & 0.5 & \\
\hline & $X$ Chitalpa & tashkentensis & 'Summer bells' & 0.4 & \\
\hline
\end{tabular}

Table 4

Density and microclimate factors calculated for the study sectors.

\begin{tabular}{lcc}
\hline Sector & $\mathrm{K}_{\mathrm{d}}$ & $\mathrm{K}_{\mathrm{mc}}$ \\
\hline 107 & 0.8 & 0.8 \\
108 & 0.8 & 0.8 \\
202 & 0.8 & 1.0 \\
203 & 0.8 & 0.9 \\
204 & 0.8 & 0.9 \\
301 & 1.1 & 1.0 \\
302 & 1.1 & 1.0 \\
\hline
\end{tabular}

would increase by $17 \%$ for LAW.

\subsection{Irrigation performance}

As was expected for a Mediterranean climate, the mean RRS value is small (0.23), and a constant deficit during the study season was observed (see Fig. 6). Only $74 \mathrm{~mm}$ of $\mathrm{ET}_{0}(923 \mathrm{~mm})$ was supplied by rainfall during the study season.

Fig. 5 shows that RRS was small and no difference was observed either among plant categories or zones. July showed the largest value coinciding with the occurrence of two heavy storm events. Thus, it is highlighted that plants need irrigation for their development.

The RWS values presented in Table 5 were determined considering the actual irrigation depth $\mathrm{H}_{\mathrm{b}}$ and two hypotheses for ET estimation: (1) using the $\mathrm{K}_{\mathrm{C}}$ assigned by the garden's manager $\left(\mathrm{ET}=\mathrm{ET}_{\mathrm{Kc}}\right)$, and (2) using the $\mathrm{K}_{\mathrm{L}}$ values assigned by WUCOLS III $\left(\mathrm{ET}=\mathrm{ET}_{\mathrm{KL}}\right)$.

Table 5 shows that estimations of both $\mathrm{K}_{\mathrm{C}}$ and $\mathrm{K}_{\mathrm{L}}$ lead to over-irrigation in July and August although their estimations for the other months are more accurate. The $\mathrm{K}_{\mathrm{C}}$ values for TREE and to a lesser extent for LAW, yielded optimum values compared to other plant types. Given that $\mathrm{H}_{\mathrm{b}}$ is the same for both $\mathrm{RWS}_{\mathrm{Kc}}$ and RWS $\mathrm{KL}_{\mathrm{L}}$, the higher $\mathrm{RWS}_{\mathrm{KL}}$ values point out that much higher over irrigation would result if $\mathrm{K}_{\mathrm{L}}$ were used to calculate the irrigation requirements.

Fig. 6 presents the percentage of water not wasted when $\mathrm{ET}_{\mathrm{Kc}}$ is used to estimate the irrigation requirements instead of $\mathrm{ET}_{\mathrm{KL}}$.

Water savings of $200 \%$ are observed in TREE in August. $\mathrm{K}_{\mathrm{L}}$ results in lower water consumption for LAW in October.

\subsection{Soil water balance}

Fig. 7 presents the variation in the soil water content during the irrigation season.

The amount of water that reaches the soil (I+ Pe-ET-D) maintains soil water content between the field capacity (FC) level and the lower limit of the easily available water range (EA). As shown in Fig. 7, the soil water content decreased below the threshold of the plant available water during the late spring, in all plant categories except in LAW, which was the category in which the least differences were observed between $\mathrm{RWS}_{\mathrm{KL}}$ and RWS $\mathrm{Kc}_{\mathrm{Kc}}$ (see Fig. 5). The irrigation events increase the soil water content above the saturated level which increases the risk of surface runoff and root damage.

\section{Discussion}

In this paper we have study the suitability in the operation of a smart irrigation system. For this purpose, we have compared the current practices of the garden's manager using a set of $\mathrm{K}_{\mathrm{C}}$ coefficients with the $\mathrm{K}_{\mathrm{L}}$ coefficients estimated through the WUCOLS III methodology. We have analyzed the volume and the schedule of the applied irrigation and assessed the soil water availability.

In general, the plants water requirements determined by either $\mathrm{K}_{\mathrm{C}}$ or $\mathrm{K}_{\mathrm{L}}$, resulted in over-irrigation. The water demand estimated by $\mathrm{K}_{\mathrm{C}}$ 

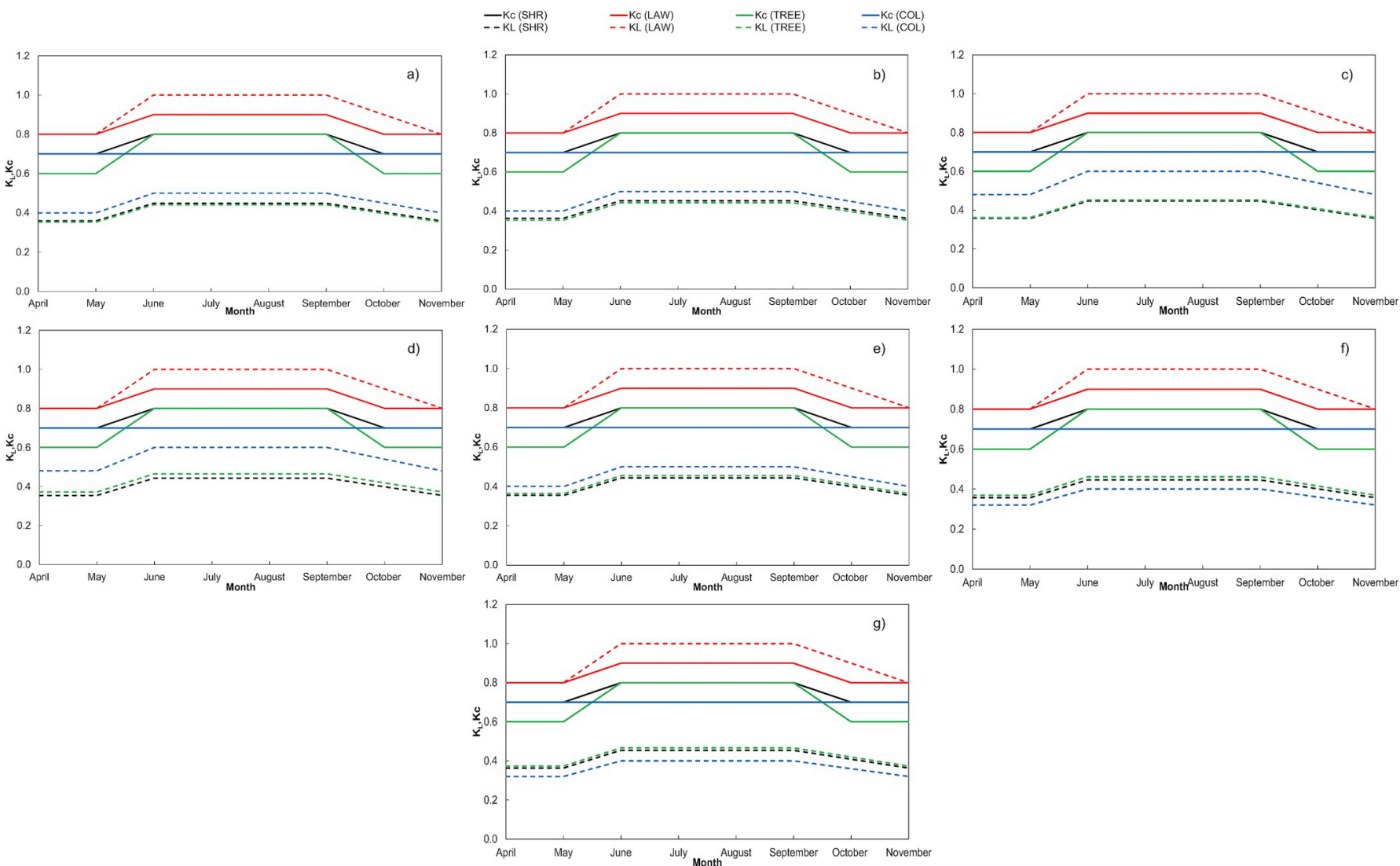

Fig. 4. $\mathrm{K}_{\mathrm{C}}$ and $\mathrm{K}_{\mathrm{L}}$ coefficients for each plant category and sectors: 107 (a), 108 (b), 202 (c), 203 (d), 204 (e), 301 (f), and 302 (g).
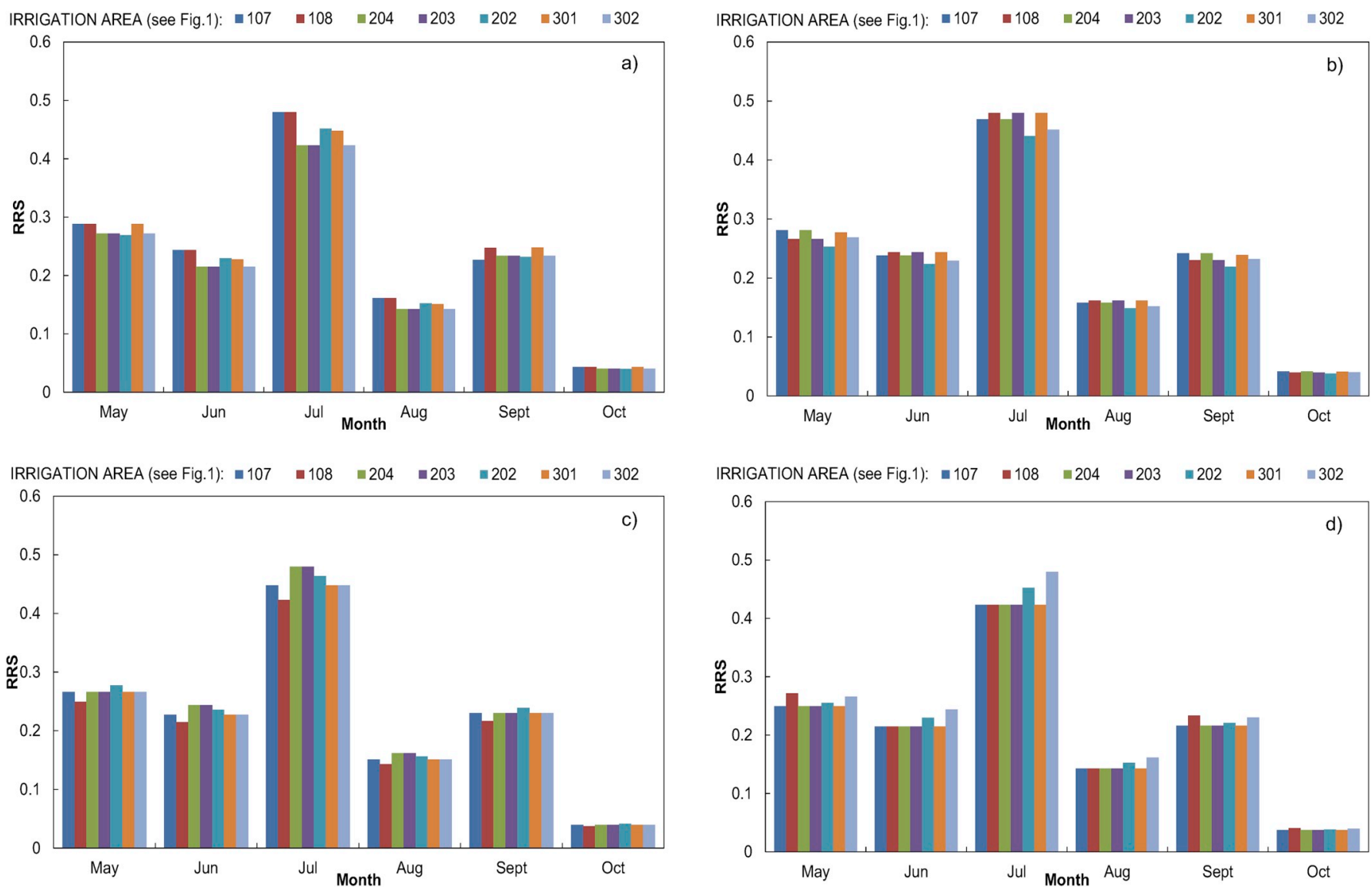

Fig. 5. Variation in RRS during the season for the evaluated sectors and plant categories: COL (a), LAW (b), SHR (c) and TREE (d). 

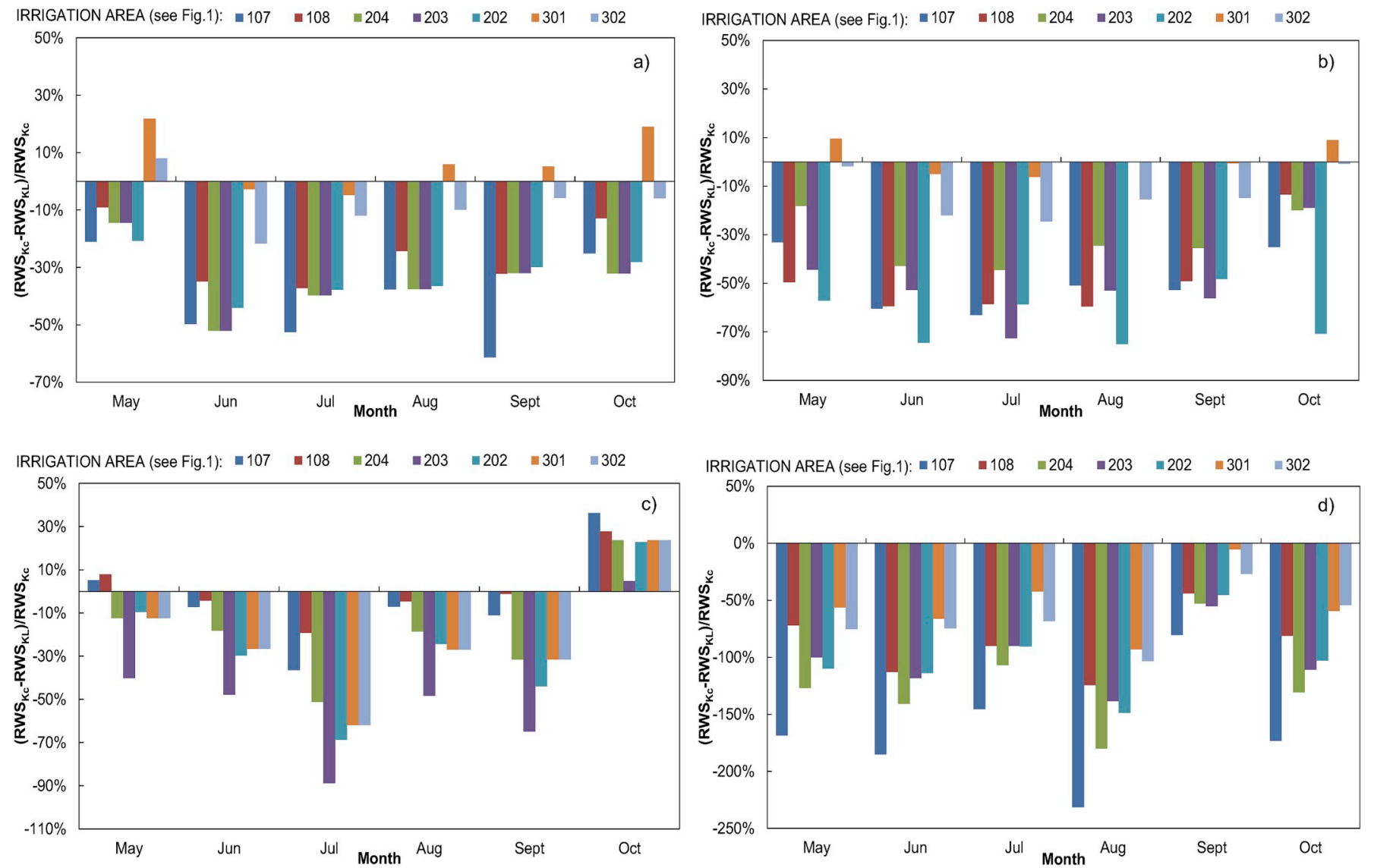

Fig. 6. Differences between RWS ${ }_{\mathrm{KL}}$ and RWS $\mathrm{Kc}_{\mathrm{Kc}}$ in COL (a), LAW (b), SHR (c) and TREE (d).

Table 5

RWS for programmed crop coefficient $\mathrm{K}_{\mathrm{c}}$ and proposed landscape coefficient $\mathrm{K}_{\mathrm{L}}$.

\begin{tabular}{|c|c|c|c|c|c|c|c|c|c|c|c|c|c|c|c|c|c|c|}
\hline \multirow{2}{*}{\multicolumn{2}{|c|}{$\begin{array}{l}\text { Sector } \\
\text { Typology }\end{array}$}} & \multicolumn{6}{|c|}{ RWS $\mathrm{ET}_{\mathrm{C}}$} & \multicolumn{11}{|c|}{ RWS $\mathrm{ET}_{\mathrm{L}}$} \\
\hline & & May & Jun & Jul & Aug & Sep & Oct & May & & Jun & & Jul & & Aug & & Sep & & Oct \\
\hline \multirow[t]{4}{*}{107} & COL & 1.33 & 1.95 & 1.56 & 1.94 & 1.76 & 1.63 & 1.61 & 2.92 & & 2.38 & & 2.67 & & 2.84 & & 2.04 & \\
\hline & LAW & 0.97 & 1.54 & 1.26 & 1.41 & 1.71 & 1.27 & 0.92 & 1.65 & & 1.72 & & 1.51 & & 1.90 & & 0.81 & \\
\hline & SHR & 1.21 & 1.82 & 1.46 & 1.77 & 1.86 & 1.51 & 1.61 & 2.92 & & 2.38 & & 2.67 & & 2.84 & & 2.04 & \\
\hline & TREE & 0.89 & 1.42 & 1.30 & 1.3 & 1.69 & 1.01 & 2.39 & 4.05 & & 3.19 & & 4.31 & & 3.05 & & 2.76 & \\
\hline \multirow[t]{4}{*}{108} & COL & 1.33 & 1.95 & 1.56 & 1.94 & 1.93 & 1.63 & 1.45 & 2.63 & & 2.14 & & 2.41 & & 2.55 & & 1.84 & \\
\hline & LAW & 0.89 & 1.42 & 1.30 & 1.3 & 1.69 & 1.01 & 0.82 & 1.48 & & 1.55 & & 1.36 & & 1.71 & & 0.73 & \\
\hline & SHR & 0.97 & 1.65 & 1.35 & 1.51 & 1.71 & 1.27 & 1.45 & 2.63 & & 2.14 & & 2.41 & & 2.55 & & 1.44 & \\
\hline & TREE & 1.25 & 1.71 & 1.51 & 1.73 & 1.91 & 1.37 & 2.15 & 3.64 & & 2.87 & & 3.88 & & 2.75 & & 2.48 & \\
\hline \multirow[t]{4}{*}{204} & COL & 1.25 & 1.71 & 1.51 & 1.73 & 1.91 & 1.37 & 1.43 & 2.6 & & 2.11 & & 2.38 & & 2.52 & & 1.81 & \\
\hline & LAW & 0.97 & 1.65 & 1.35 & 1.51 & 1.71 & 1.27 & 1.09 & 1.95 & & 2.04 & & 1.79 & & 2.25 & & 0.97 & \\
\hline & SHR & 1.21 & 1.82 & 1.46 & 1.77 & 1.86 & 1.51 & 1.43 & 2.60 & & 2.11 & & 2.38 & & 2.52 & & 1.81 & \\
\hline & TREE & 0.89 & 1.42 & 1.30 & 1.30 & 1.69 & 1.01 & 2.02 & 3.42 & & 2.69 & & 3.64 & & 2.58 & & 2.33 & \\
\hline \multirow[t]{4}{*}{203} & $\mathrm{COL}$ & 1.25 & 1.71 & 1.51 & 1.73 & 1.91 & 1.37 & 1.43 & 2.6 & & 2.11 & & 2.38 & & 2.52 & & 1.81 & \\
\hline & LAW & 0.97 & 1.65 & 1.35 & 1.51 & 1.71 & 1.27 & 1.36 & 2.44 & & 2.55 & & 2.24 & & 2.82 & & 1.21 & \\
\hline & SHR & 0.97 & 1.65 & 1.35 & 1.51 & 1.71 & 1.27 & 1.40 & 2.52 & & 2.33 & & 2.31 & & 2.67 & & 1.51 & \\
\hline & TREE & 0.89 & 1.42 & 1.30 & 1.30 & 1.69 & 1.01 & 1.78 & 3.10 & & 2.47 & & 3.10 & & 2.62 & & 2.13 & \\
\hline \multirow[t]{4}{*}{202} & COL & 1.11 & 1.68 & 1.43 & 1.62 & 1.81 & 1.32 & 1.34 & 2.42 & & 1.97 & & 2.21 & & 2.35 & & 1.69 & \\
\hline & LAW & 1.15 & 1.75 & 1.41 & 1.68 & 1.82 & 1.45 & 1.26 & 2.27 & & 2.38 & & 2.09 & & 2.62 & & 1.12 & \\
\hline & SHR & 0.91 & 1.49 & 1.33 & 1.36 & 1.70 & 1.06 & 1.43 & 2.60 & & 2.11 & & 2.38 & & 2.52 & & 1.81 & \\
\hline & TREE & 0.92 & 1.53 & 1.35 & 1.40 & 1.70 & 1.10 & 1.93 & 3.27 & & 2.57 & & 3.48 & & 2.47 & & 2.23 & \\
\hline \multirow[t]{4}{*}{301} & COL & 1.33 & 1.84 & 1.47 & 1.84 & 1.93 & 1.63 & 1.04 & 1.89 & & 1.54 & & 1.73 & & 1.83 & & 1.32 & \\
\hline & LAW & 0.97 & 1.54 & 1.26 & 1.41 & 1.71 & 1.27 & 1.09 & 1.95 & & 2.04 & & 1.79 & & 2.25 & & 0.97 & \\
\hline & SHR & 1.15 & 1.8 & 1.45 & 1.73 & 1.82 & 1.45 & 1.04 & 1.89 & & 1.54 & & 1.73 & & 1.83 & & 1.32 & \\
\hline & TREE & 0.89 & 1.42 & 1.30 & 1.30 & 1.69 & 1.01 & 1.39 & 2.36 & & 1.85 & & 2.51 & & 1.78 & & 1.61 & \\
\hline \multirow[t]{4}{*}{302} & COL & 1.25 & 1.71 & 1.51 & 1.73 & 1.91 & 1.37 & 1.15 & 2.08 & & 1.69 & & 1.90 & & 2.02 & & 1.45 & \\
\hline & LAW & 0.97 & 1.54 & 1.26 & 1.41 & 1.71 & 1.27 & 1.09 & 1.95 & & 2.04 & & 1.79 & & 2.25 & & 0.97 & \\
\hline & SHR & 1.11 & 1.68 & 1.43 & 1.62 & 1.81 & 1.32 & 1.13 & 2.05 & & 1.78 & & 1.87 & & 2.08 & & 1.33 & \\
\hline & TREE & 0.97 & 1.65 & 1.35 & 1.51 & 1.71 & 1.27 & 1.70 & 2.88 & & 2.27 & & 3.07 & & 2.17 & & 1.96 & \\
\hline
\end{tabular}



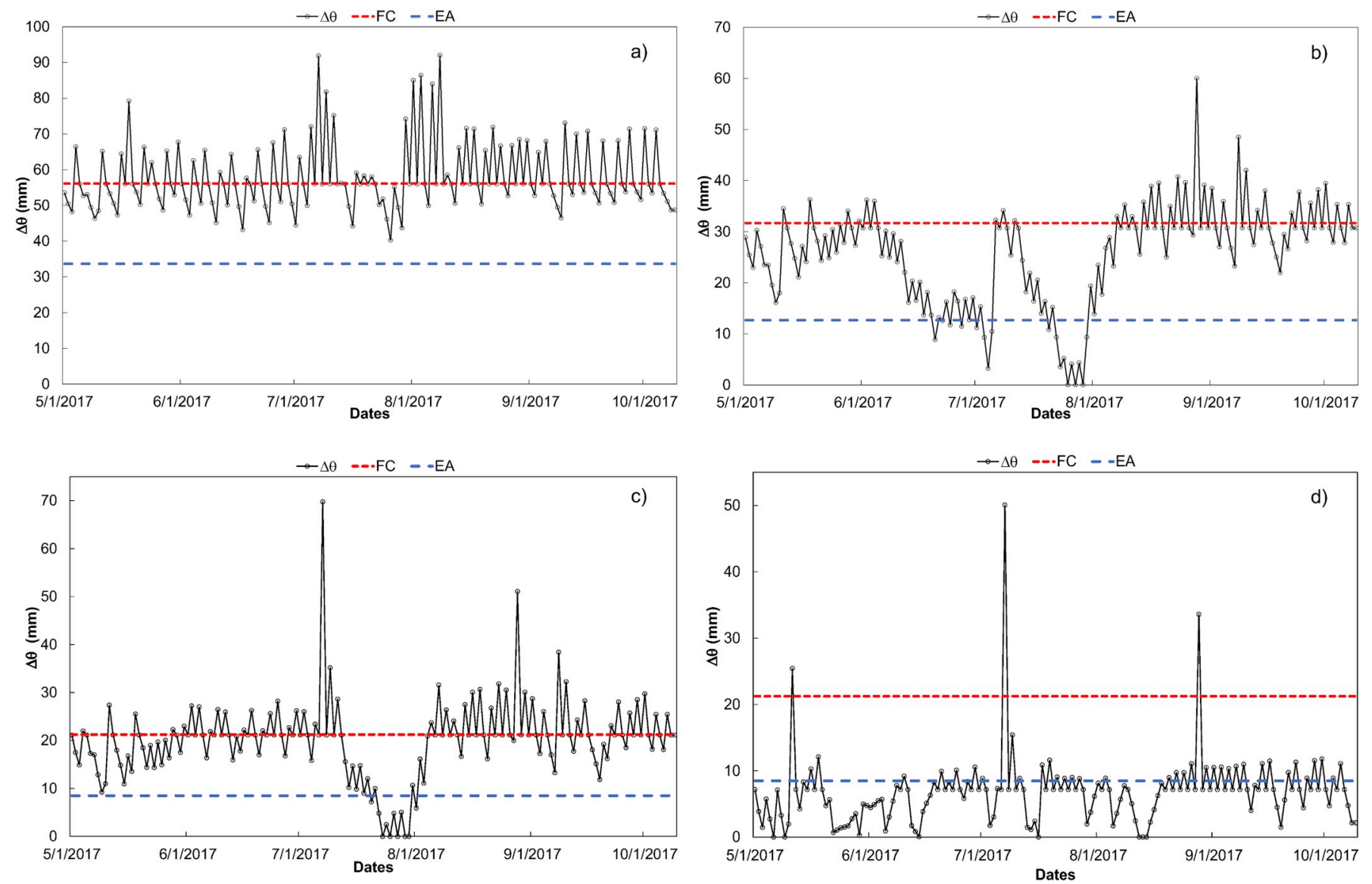

Fig. 7. Soil water balance for each plant type for (a) COL; (b) TREE; (c) SHR and (d) LAW.

and $\mathrm{K}_{\mathrm{L}}$ would have been $78646 \mathrm{~m}^{3}$ and $50918 \mathrm{~m}^{3}$, respectively. Thus, a $35.2 \%\left(27728 \mathrm{~m}^{3}\right)$ of the consumed water would have been saved using the first coefficient. The highest savings would correspond to SHR and COL with 15703 y $12092 \mathrm{~m}^{3}$, respectively.

As it was stated in the introduction section, some studies reported that automated system and/or adequate operational criteria resulted in significant water savings (Pérez-Urrestarazu et al., 2018; Salvador et al., 2011; Martínez Gimeno, 2014). The Valdebebas' results agree with them and, since its irrigation system is fully controlled and automated, they also highlight the need for a proper determination of irrigation depth. Although nowadays municipalities, sport fields and private urbanizations are provided with technological devices for precision irrigation, over irrigation results a common practice when a proper water control is lacked, and also the irrigation scheduling is based on either the technicians' experience or the appearance of ornamental plants. However, when water is scarce, they get worried and make investments to optimize urban water use.

The WUCOLS III method may have the advantage to provide a more accurate estimation of the water demands compared to the common $\mathrm{K}_{\mathrm{C}}$ methods, since it considers three coefficients in the determination of the reference evapotranspiration. Nonetheless, the WUCOLS III method can also generate an over-estimation of the water use requirements if $K_{s}$, $K_{d}$ or $\mathrm{K}_{\mathrm{mc}}$ are not properly determined. Since the $\mathrm{K}_{\mathrm{s}}$ values are determined using the average value for the existing plants, $K_{d}$ and $K_{m c}$ could be adapted for specific plant types.

Otherwise, the lack of standards for $\mathrm{K}_{\mathrm{s}}, \mathrm{K}_{\mathrm{d}}$ and $\mathrm{K}_{\mathrm{mc}}$ estimation is a disadvantage to determinate $\mathrm{K}_{\mathrm{L}}$ with accuracy. The $\mathrm{K}_{\mathrm{s}}$ coefficient, either assigned by the maintenance personnel (once the garden set up is finished) or by the landscaper (at the design stage), regards to generic plant species and, its extrapolation to the specific plant varieties found in gardens would have limitations. The $\mathrm{K}_{\mathrm{d}}$ coefficient is associated to the leaf area index surface, which is difficult to measure in ornamental gardens due to their heterogeneity. Finally, the $\mathrm{K}_{\mathrm{mc}}$ coefficient is associated to the temperature and wind variation across the park, which results in technical difficulties for its calculation since gardens and parks are heterogeneous not only by their multiple plant species but also by their structure.

The information available from the weather station and the tools for controlling the irrigation network (both the software and the operating elements) undoubtedly provided enough flexibility to manage the irrigation in a more precise and accurate way. Since many plant types are over-irrigated during certain months, further studies could be conducted to analyze divergence between $\mathrm{K}_{\mathrm{L}}$ and $\mathrm{K}_{\mathrm{C}}$. Provided that the method for $K_{s}$ estimation in this work is reasonable and that the $K_{d}$ value, or plant density is considered constant, the comparison between $\mathrm{K}_{\mathrm{L}}$ and $\mathrm{K}_{\mathrm{C}}$ could be used to deduce the optimum $\mathrm{K}_{\mathrm{mc}}$ values for each sector that could provide valuable information about the local differences among sectors.

The accuracy and reliability in the estimation of water requirements on parks and gardens by WUCOLS III could be improved considering some tools such as satellite thermal images or the Normalized Difference Vegetation Index (NDVI). The first can help to monitor temperature variation within a microclimate (Alchanatis et al., 2010; Jones et al., 2009). The NDVI can be used to estimate the plants' leaf density and their evapotranspiration (Li et al., 2019; Segovia-Cardozo et al., 2019). Although these tools are used for horticultural crops they are seldom developed for ornamental species. Likewise, green areas could adopt precision irrigation by monitoring "in situ" soil water content, with soil water probes. Thus, the soil water content data will be transferred to the irrigation central station, and lately used for the determination of the doses and the frequency of irrigation. 


\section{Conclusions}

In this paper, the performance of a smart irrigation system was assessed. The irrigation infrastructure, which is located at the Valdebebas urban development in Madrid (Spain), is made up of trickle irrigation emitters (DI) and SDI units. The irrigation system is fed by a reclaimed wastewater network and is automated for control of the irrigation efficiency. The irrigation scheduling and operation is managed by the maintenance staff who calculate the crop coefficients and the frequency of the irrigation events based on the climatic variables measured at a local weather station. The human decisions are supported by control software that operates the whole irrigation system.

Despite the number of control devices and the automation of the system, the on-the-ground decisions relating to the assignment of crop coefficients have a significant effect on the efficiency of irrigation. The estimations carried out in the present work showed that the use of the landscape coefficient leads to over-irrigation in most of the study areas and a subsequent reduction in water use efficiency. The operating decisions are based solely on climatic variables, and not on the soil water availability. This can lead to inefficient management of the irrigation because the saturation level is often reached, which leads to surface runoff or, alternatively, under-irrigation leading to the soil water content dropping below the easily available water threshold.

Therefore, smart irrigation systems and, specifically, the study irrigation system in Valdebebas, allow for automation and control of the irrigation system which helps to optimize the irrigation operating conditions. However, the on-the-ground decisions, such as the determination of the crop coefficient used to determine the irrigation depth, do influence the efficiency of the water use.

\section{Acknowledgement}

The authors wish to thank the Valdebebas management board, Junta de Compensación de Valdebebas, and the irrigation manager for the information provided. We also wish to thank the CONICYT who sponsored the PFCHA/BCH 72190480 scholarship for Freddy Canales.

\section{References}

Alchanatis, V., Cohen, Y., Cohen, S., Moller, M., Sprinstin, M., Meron, M., Tsipris, J., Saranga, Y., Sela, E., 2010. Evaluation of different approaches for estimating and mapping crop water status in cotton with thermal imaging. Precis. Agric. 11, 27-41. https://doi.org/10.1007/s11119-009-9111-7.

Angelakis, A.N., Gikas, P., 2014. Water reuse: overview of current practices and trends in the world with emphasis on EU states. Water Util. J. 8, 67-78.

Ayuntamiento, de Madrid, 2018. Agua Regenerada: Reutilización Planificada. [WWW Document]. URL. https://www.madrid.es/portales/munimadrid/es/Inicio/ Buscador-Simple/Reutilizacion-planificada?vgnextfmt = default\&vgnextoid = a3651a824d4ae210VgnVCM2000000c205a0aRCRD\&vgnextchannel = 8db7566813946010VgnVCM100000dc0ca8c0RCRD accessed 10.12.18.

Brandt, M.J., Johnson, K.M., Elphinston, A.J., Ratnayaka, D.D., Brandt, M.J., Johnson, K.M., Elphinston, A.J., Ratnayaka, D.D., 2017. The demand for potable water. Twort's Water Supply 1-36. https://doi.org/10.1016/B978-0-08-100025-0.00001-6.

Costello, L.R., 1994. WUCOLS Water Use Classification of Landscape Species. [WWW Document]. Univ. CALIFORNIA, Coop. Ext. URL. http://ucanr.edu/sites/oc/files/ 132534.pdf accessed 12.12.18.

Costello, L.R., Jones, K.S., 2014. WUCOLS IV, Water Use Classification of Landscape Species. (Davis, California).

Davis, S.L., Dukes, M.D., 2015. Methodologies for successful implementation of smart irrigation controllers. J. Irrig. Drain. Eng. 141 0000804, Comment: 04014055-104014055-9. https://doi.org/10.1061/(ASCE)IR.1943-4774.

Haley, M., Dukes, M., Miller, G., 2007. Residential irrigation water use in Central Florida. J. Irrig. Drain. Eng. 133, 427-434. https://doi.org/10.1061/(ASCE)0733-9437(2007) 133:5(427).

Hof, A., Wolf, N., 2014. Estimating potential outdoor water consumption in private urban landscapes by coupling high-resolution image analysis, irrigation water needs and evaporation estimation in Spain. Landsc. Urban Plan. 123, 61-72. https://doi.org/10. 1016/J.LANDURBPLAN.2013.12.010.

Jones, H.G., Serraj, R., Loveys, B.R., Xiong, L., Wheaton, A., Price, A.H., 2009. Thermal infrared imaging of crop canopies for the remote diagnosis and quantification of plant responses to water stress in the field. Funct. Plant Biol. 36, 978-989. https://doi.org/ 10.1071/fp09123.

Levine, G., 1982. Relative Water Supply, an explanatory variable for irrigations systems. In: Tech. Rept. No 6; the Determinations of Irrigation Projects in Developing Countries, (Ithaca, NY).

Li, Congcong, Li, H., Li, J., Lei, Y., Li, Chunqiang, Manevski, K., Shen, Y., 2019. Using NDVI percentiles to monitor real-time crop growth. Comput. Electron. Agric. 162, 357-363. https://doi.org/10.1016/J.COMPAG.2019.04.026.

Martínez Gimeno, M.A., 2014. Estrategia para la evaluación agronómica, hidráulica y energética en jardinería. Aplicación a la gestión de jardines públicos. Universitat Politécnica de Valencia.

Mateos, L., González-Dugo, M.P., Testi, L., Villalobos, F.J., 2013. Monitoring evapotranspiration of irrigated crops using crop coefficients derived from time series of satellite images. I. Method validation. Agric. Water Manag. 125, 81-91. https://doi. org/10.1016/J.AGWAT.2012.11.005.

Mini, C., Hogue, T.S., Pincetl, S., 2014. Estimation of residential outdoor water use in Los Angeles, California. Landsc. Urban Plan. 127, 124-135. https://doi.org/10.1016/J. LANDURBPLAN.2014.04.007.

Moncef, H., Khemaies, Z., 2016. An analytical approach to predict the moistened bulb volume beneath a surface point source. Agric. Water Manag. 166, 123-129. https:// doi.org/10.1016/j.agwat.2015.12.020.

Nouri, H., Beecham, S., Hassanli, A.M., Kazemi, F., 2013. Water requirements of urban landscape plants: a comparison of three factor-based approaches. Ecol. Eng. 57, 276-284. https://doi.org/10.1016/J.ECOLENG.2013.04.025.

Patil, P., Desai, B.L., 2013. Intelligent irrigation control system by employing wireless sensor networks. Int. J. Comput. Appl. 79, 33-40.

Pérez-Urrestarazu, L., Egea, G., Ruiz-Alcalá, C., Roldán-Olmo, F., Fernández-Cañero, R., 2018. Water management assessment in a historic garden: the case study of the Real Alcazar (Seville, Spain). Urban For. Urban Green. 29, 192-199. https://doi.org/10. 1016/J.UFUG.2017.11.020.

Reyes-Paecke, S., Gironás, J., Melo, O., Vicuña, S., Herrera, J., 2019. Irrigation of green spaces and residential gardens in a Mediterranean metropolis: gaps and opportunities for climate change adaptation. Landsc. Urban Plan. 182, 34-43. https://doi.org/10. 1016/J.LANDURBPLAN.2018.10.006.

Rodríguez-Sinobas, L., Zubelzu, S., Perales-Momparler, S., Canogar, S., 2018. Techniques and criteria for sustainable urban stormwater management. The case study of Valdebebas (Madrid, Spain). J. Clean. Prod. 172, 402-416. https://doi.org/10.1016/ j.jclepro.2017.10.070.

Segovia-Cardozo, D.A., Rodríguez-Sinobas, L., Zubelzu, S., 2019. Water use efficiency of corn among the irrigation districts across the Duero river basin (Spain): estimation of local crop coefficients by satellite images. Agric. Water Manag. 212, 241-251. https://doi.org/10.1016/J.AGWAT.2018.08.042.

Salvador, R., Bautista-Capetillo, C., Playán, E., 2011. Irrigation performance in private urban landscapes: a study case in Zaragoza (Spain). Landsc. Urban Plan. 100 302-311. https://doi.org/10.1016/J.LANDURBPLAN.2010.12.018.

Subbaiah, R., 2013. A review of models for predicting soil water dynamics during trickle irrigation. Irrig. Sci. 31, 225-258. https://doi.org/10.1007/s00271-011-0309-x.

Todorovic, M., Riezzo, E.E., Buono, V., Zippitelli, M., Galiano, A., Cantore, V., 2016. Hydro-tech: an automated smart-tech decision support tool for eco-efficient irrigation management. Int. Agric. Eng. J. 25, 44-56.

Vidana Gamage, D.N., Biswas, A., Strachan, I.B., 2018. Actively heated fiber optics method to monitor three-dimensional wetting patterns under drip irrigation. Agric. Water Manag. 210, 243-251. https://doi.org/10.1016/j.agwat.2018.08.019.

Yao, W.W., Ma, X.Y., Li, J., Parkes, M., 2011. Simulation of point source wetting pattern of subsurface drip irrigation. Irrig. Sci. 29, 331-339. https://doi.org/10.1007/ s00271-010-0236-2.

Zhang, F., 2011. Research on water-saving irrigation automatic control system based on internet of things. In: 2011 International Conference on Electric Information and Control Engineering, ICEICE 2011 - Proceedings, . https://doi.org/10.1109/ICEICE. 2011.5778297. 